\author{
Stanisław Gajda \\ Uniwersytet Opolski \\ E-MAIL: stgajda@uni.opole.pl
}

\title{
Język w nauce \\ (w perspektywie filozoficzno-lingwistycznej) ${ }^{1}$
}

\begin{abstract}
STRESZCZENIE
Jądrem naukowego postępowania badawczego jest dążenie do zbudowania teorii. Struktura pełnej teorii obejmuje trzy poziomy: filozoficzny (zespół przyjętych a priori założeń ontologicznych, epistemologicznych i aksjologicznych), teoretyczno-metodologiczny (najbardziej ogólne twierdzenia i abstrakcyjne pojęcia, konceptualizujące strukturalizujące i interpretujące teoretyzowany fragment świata) oraz empiryczny (empiryczne twierdzenia i pojęcia orzekające coś bezpośrednio o badanych obiektach). W swych podstawach filozoficznych współczesne teorie budowane na naukach humanistycznych powinny uwzględniać reinterpretację relacji między światem przedmiotowym, umysłem i językiem, dokonaną przez zwroty podmiotowy i językowy, a także uznać wielość sposobów istnienia rzeczywistości (obiektywne: TO i TE/TEN oraz subiektywne: JA i MY). W konsekwencji pełna teoria języka musi przyjąć, iż język nie tylko wyraża to, co w umyśle i komunikuje innym, lecz także kształtuje ludzkie myślenie i oddziałuje na obiektywną rzeczywistość. Język w nauce jest determinowany przez kontakt społeczno-kulturowy (tradycję) oraz kontekst komunikacyjny, ale na jego kształt ma też wpływ indywidualne, podmiotowe poczucie stylowe.

SŁOWA KLUCzowE: nauka, teoria, sposoby istnienia rzeczywistości, język, style intelektualne, poczucie stylowe
\end{abstract}

1.

Jeden z bohaterów Dżumy A. Camusa cały czas pracuje nad pierwszym zdaniem swojej powieści. Jest przekonany, że kiedy już je napisze, będzie miał całą książkę, bo stanie się ona rozwinięciem tego zdania. Czytelnik, aby to zdanie zrozumieć i docenić, powinien przeczytać całą książkę.

To zachowanie może wydawać się dziwactwem. Kryje się w nim jednak głębszy sens. Każdy z nas ma własne doświadczenia z zaczynaniem niespontanicznych tekstów. Istnieje spora literatura naukowa poświęcona tzw. incipitom, początkom tekstów. Okazuje się, że są one w wielu typach tekstów

Jest to tekst wykładu wygłoszonego na Letniej Szkole Młodych Pedagogów we wrześniu 2017 roku. 
bardzo standardowe (por. w baśniach formuły: „Za górami za lasami...”; „Żył sobie...”). Nawet w dążącej do oryginalności literaturze pięknej pod powierzchniową różnorodnością da się dostrzec głębsze prawidłowości. Jeszcze wyraźniejsze są one w tekstach naukowych. Nasuwa się więc wniosek, iż tekstowe incipity muszą mieć związek z mechanizmami budowy tekstu oraz $\mathrm{z}$ regułami komunikowania się. Te mechanizmy i reguły ograniczają nas, narzucają wybory w pewnych granicach, nie zamykając całkowicie drogi do odkrywania nowych sposobów zaczynania tekstów.

Aby nie pozostać jak postać z DżumY, ciągle przy poszukiwaniu pierwszego, doskonałego, „zarodkowego” zdania, trzeba zdecydować się na choćby nieidealne rozwiązanie. W przypadku mojego tekstu zastanawiałem się, czy nie uciec się do aforystycznych wypowiedzi „olbrzymów” i wybrać jako motta np. coś z L. Wittgensteina („Myślenie polega w istocie na operowaniu znakami”) czy L. Wygotskiego („Myśl nie jest jedynie wyrażona w słowie, lecz spełnia się w słowie"). W końcu stanęło na rozwiązaniu, które polega na „streszczeniu” dwu części mojej wypowiedzi.

W części pierwszej (2.) - filozoficzno-naukoznawczej - swoje rozważania pragnę poświęcić głównie teorii naukowej i mogłoby ją otworzyć zdanie: „Nie ma rzeczy bardziej praktycznej niż dobra teoria”, choć z zastrzeżeniem: „Teoria to bardzo niebezpieczna rzecz”. Natomiast część drugą (3.) - o komunikacji w nauce - chyba najlepiej sumuje normatywne zdanie: „Należy mówić/pisać do rzeczy i do ludzi”.

\section{1.}

Życie to działanie, które obejmuje też poznawanie rzeczywistości, siebie i otaczającego świata. Wśród głównych odmian poznania - potocznego, artystycznego, religijnego oraz naukowego - w czasach nowożytnych w dominującej aurze intelektualnej wyróżnioną pozycję przyznawano poznaniu naukowemu i wiedzy naukowej. Do dziś toczy się filozoficzny spór (bo kierowany raczej filozoficznymi intuicjami niż niepodważalnymi racjami) o status poznawczy tej wiedzy. Wyraża się on wieloma stanowiskami na skali realizm - antyrealizm/konstruktywizm. Klasyczni realiści uznają, iż nauka odkrywa prawdy o świecie niezależne od poznającego podmiotu. Natomiast według konstruktywistów tworzy ona struktury teoretyczne, umożliwiające konceptualizację danych doświadczenia (zob. Zeidler, 1993; Zybertowicz, 1995; Bińczyk, 2015).

Większość naukowców jest raczej realistami. Uważa bowiem, iż nauka implikuje stanowisko realistyczne. Ich zdaniem tylko realizm wyjaśnia fakt prewidystycznej i technologicznej roli oraz skuteczności nauki. To stanowi- 
sko podchwytuje się we współczesnej polityce naukowej, w której zarzuca się czystej nauce dominacje tendencji „teoretycystycznej” i podkreśla fakt, że nauka to przede wszystkim działalność polegająca na świadomym interweniowaniu w rzeczywistość, a w znacznie mniejszym stopniu na jej reprezentowaniu w teoriach.

Wydaje się jednak, że zwłaszcza w naukach humanistycznych i społecznych natura rzeczywistości społeczno-kulturowej - jej złożoność, zmienność i różnorodność - wymaga ciągłego poszukiwania alternatyw dla niekwestionowanych sposobów ujmowania świata oraz odkrywania nieuświadamianych wcześniej możliwości ludzkich. To dążenie do coraz głębszego i pełniejszego poznania świata ludzkiego oraz przekazywania uzyskanej wiedzy innym powinno łączyć się jednak z podkreślaniem także konstruktywistycznego wymiaru tej wiedzy oraz konieczności jej udoskonalania. Ta wiedza ma pomóc w przeobrażaniu rzeczywistości. Ma więc także wymiar performatywny. Trzeba też sobie uświadamiać, że prawda w świecie człowieka nie może być „jedna jedyna”, stąd dyskurs naukowy powinien mieć raczej postać dialogiczną niż instruktażowo-monologiczną.

W studiach nad nauką trwa jeszcze spór między stanowiskiem esencjalistyczno-teoriocentrycznym, który sprowadza wiedzę naukową do teorii (tu lokuje się zarówno realizm, jak i konstruktywizm), a nieesencjalistycznym ujęciem tej wiedzy, polegającym na przejściu od myślenia o danym obiekcie, który ma być opisany przez pojęcie (teorię), do myślenia o praktykach, w których używa się tego pojęcia. W tym ujęciu wiedza jest rezultatem i konsekwencją usytuowania praktyk i nie da się jej wyabstrahować w teoretycznych pojęciach i teoriach opartych na reprezentacji. A praktyki naukowe mają wymiary: materialny, społeczny i dyskursywny. Zawierają obiekty, z którymi i poprzez które się działa, oraz kontekst, w którym są usytuowane. Mają więc performatywny charakter. Interesujący nas szczególnie wymiar dyskursywny praktyk przeciwstawia się ujęciom reprezentatywnym, preferującym język wyrażający ustalone, obiektywne znaczenia i konwencjonlną retorykę. W tym sposobie pisania preferuje się język „popularny”, ucieka się od hermetyzmu, łączy się styl analityczny ze stylem eseistycznym, nie stroni się od metaforyzacji, odchodzi się od linearnego wywodu itp.

Obraz niehomogeniczności nauki można dopełnić jej bardzo rzucającą się w oczy niejednorodnością, wynikającą z tendencji specjalizacyjnych. W ciągu dwu ostatnich stuleci liczba dyscyplin sięgnęła kilku tysięcy, a przedstawiciele jednej dyscypliny nie są $\mathrm{w}$ stanie orientować się w problematyce wyłanianych subdyscyplin, specjalności i specjalizacji (w niektórych dyscyplinach da się wskazać setki „poddyscyplin”). Mapowanie przestrzeni naukowej 
utrudniają nowe fragmentaryzacje, m.in. związane z interdyscyplinarnością, z pojawieniem się coraz to nowych zwrotów, orientacji, studies pól dyskursywnych, kompleksów metodycznych, zogniskowań, kierunków itp. Granice tradycyjnych już dyscyplin stają się coraz bardziej arbitralne.

Takiemu rozwojowi nauki towarzyszy lawinowy wzrost liczby publikacji, co przy utrudnieniach lub wręcz zanikaniu współpracy i dyskusji naukowej grozi załamaniem komunikacji, choć wydawać się to może absurdalne w dobie współczesnej rewolucji w technologiach komunikacyjnych. Efektywna komunikacja naukowa może przebiegać wówczas, gdy badacze są w stanie wypracować i respektować $\mathrm{w}$ aktach poznawczych i komunikacyjnych pewne wspólne ustalenia. Bez ciągłego rozważania i rewidowania wspólnych założeń trudno sobie wyobrazić naukową kooperację oraz oczekiwać sukcesów naukowych.

\section{2.}

Dla zdrowia całej nauki oraz każdej dyscypliny korzystna jest refleksyjność, która nakazuje zastanawianie się nad swoimi ontycznymi i epistemicznymi oraz metodologicznymi fundamentami (a także instytucjonalnymi). Istnieje bowiem obawa, że rozwój mogą hamować dawno przyjęte założenia, które stały się dogmatyczną ideologią (obok konformizmu i instytucjonalnej inercji). Wymaga tej refleksyjności jedna z norm ideału nauki nowożytnej (por. wymóg krytycyzmu i zorganizowanego sceptycyzmu). W świetle metanaukowej refleksji nauka okazuje się przestrzenią wielu zderzeń, dialektycznych przeciwieństw. Można mówić zarówno o jej jedności, jak i o różnorodności.

Jedna z opozycji wiąże się z przeciwstawianiem podejść teoriocentrycznego i antyteoretycznego. Naukę można uprawiać bez teorii (por. opisy, narracje i praktyka). Jednak nauka bez teorii w ogóle nie byłaby nauką. To one stanowią jądro wiedzy naukowej. W dyskusjach o nauce w ciągu ostatnich kilkudziesięciu lat głośne były hasła odrzucenia teorii (zwłaszcza tzw. wielkich), ale, nieco później, powrotu do nich.

Generalnie można wyróżnić trzy typy tradycji badawczej oraz postaw badawczych reprezentowanych przez:

- teoretyków, skoncentrowanych na teoriach,

- empiryków, wychodzących od danych i sceptycznych wobec teorii, ograniczających się do generalizacji niskiego rzędu,

- metodyków, wykorzystujących naśladowczo proste heurystyki i imitujących empiryków.

W realnej praktyce naukowej te trzy typy nie muszą występować rozłącznie, mogą się przenikać lub dopełniać. 
Najkrócej przedstawiając, teoria to pewien typ - hipotetyczno-generalizujący - myślenia, które przynosi spójny metodologicznie i pojęciowo system twierdzeń opisujących i wyjaśniających jakiś fragment rzeczywistości. Trzeba podkreślić, że twierdzenia teorii powinny odnosić się przede wszystkim do pewnych ogólnych zależności, a nie do jednostkowych faktów.

W dziejach nauki można wyróżnić - znane już od antyku - trzy modele teoretycznego postępowania badawczego:

- aprioryczno-dedukcyjny (platoński),

- empiryczno-indukcyjny (arystotelejski),

- dedukcyjno-indukcyjny (archimedejski).

Tak zwana pełna teoria naukowa posiada złożoną, hierarchiczno-sieciową strukturę, w której można wyróżnić trzy poziomy:

1) filozoficzny, obejmujący zespół przyjętych a priori założeń ontologicznych, epistemologicznych i aksjologicznych,

2) teoretyczno-metodologiczny, zawierający najbardziej ogólne twierdzenia i wysoce abstrakcyjne pojęcia, które dają ramową konceptualizację, strukturalizację i interpretację teoretyzowanego fragmentu rzeczywistości (dotyczą jej budowy, funkcjonowania, relacji wewnętrznych i zewnętrznych oraz rozwoju),

3) empiryczny, który orzeka coś bezpośrednio o badanych obiektach poprzez empiryczne pojęcia opisowe i empiryczne twierdzenia.

Terminem „teoria” posługujemy się jednak również wodniesieniu do konstrukcji poznawczych, które nie zawierają - przynajmniej eksplicytnie wyrażonych - wszystkich poziomów i ograniczają się do poziomu empirycznego. Różnice między teoriami mogą dotyczyć także np. zakresu obejmowanej rzeczywistości, ukierunkowania filozoficznego, stopnia adekwatności, przynależności dyscyplinarnej.

Trzeba zdawać sobie sprawę z zalet i ograniczeń teorii. Do jej plusów należy zaliczyć m.in. to, że z pozycji teoretycznych badacz może dostrzec więcej niż badacz, który obserwuje świat z bliska (grozi mu "zaślepienie” danymi). Ponadto ważny jest aspekt praktyczny teorii. F. Bacon przedstawił model nauki: Nauka teoretyczna $\rightarrow$ Nauka stosowana $\rightarrow$ Nauka praktyczna. Zgodnie z nim teoria, dzięki swej mocy sprawczej i predykacyjnej, ma wpływać na praktyczne życie. Model ten do dziś steruje politykami naukowymi i przyczynia się do deprecjacji nauk humanistycznych.

A słabości teorii? Trzeba brać pod uwagę to, że zamiłowanie do teorii może nie pozwolić dostrzec złożoności i chaosu świata. Pragnienie ładu prowadzi czasami do tworzenia obrazów świata w postaci zbyt gładkich, uproszczonych opowieści (narracji) i teorii. Ludzki umysł zdaje się też nie doceniać roli przy- 
padku i skutków ubocznych, często negatywnych. Ponadto ograniczenia teorii mogą wynikać z faktu, iż czasem wiemy więcej, niż nam się wydaje i potrafimy wyrazić. Otóż obok wiedzy jasnej, dającej się wyraźnie ująć i wyrazić, istnieje wiedza milcząca, ukryta, apofatyczna, która wypływa z doświadczenia, ma intuicyjny charakter i jest trudna/niemożliwa do zracjonalizowania. Jatrogenia teorii (szkodliwość) może wynikać także ze zbyt sztywnego trzymania się teorii - nawet teorie wyraźnie przestarzałe, o zmniejszającym się stopniu adekwatności lub wręcz fałszywe pozwalają żyć w świecie wyimaginowanym, lecz mogą szkodzić praktycznemu działaniu i życiu.

2.3.

Teorie nie powstają w próżni, w „sterylnie” czystej przestrzeni poznawczej. Rodzą się w określonej aurze intelektualnej, tak jak romantyczny duch czasu (niem. Zeitgeist) czy neopozytywistyczne konteksty uzasadnienia i odkrycia oraz dodany nieco później kontekst językowy albo współczesne ucieleśnienie i usytuowanie umysłu. Można mówić o aurze intelektualnej ogólnej, ogólnonaukowej oraz dyscyplinarnej. Stanowi ją mniej lub bardziej spójny i zorganizowany oraz zmienny i złożony system przekonań. Aura ogólna wytwarza się na podstawie wiedzy potocznej, filozoficznej, naukowej, religijnej, politycznej i artystycznej. Wpływając na dyskurs publiczny, a nawet prywatny. Zdarza się, że w określonym czasie może w niej dominować jedna $\mathrm{z}$ ideologii (np. idea nowoczesności w dobie nowożytnej oraz neoliberalna ideologia ekonomiczno-polityczna na przełomie wieku XX na XXI). W wytwarzaniu i narzucaniu tej aury decydującą rolę odgrywają dziś media.

Aurę ogólnonaukową ostatnich stuleci (nauki nowożytnej, formującej się od XVII wieku) ukształtowały przede wszystkim dwa czynniki: zwroty łączące z filozoficzną reinterpretacją relacji między trzema fundamentalnymi bytami, tj. rzeczywistością przedmiotową, umysłem i językiem, oraz światopogląd pozytywistyczny.

Klasyczna filozofia i myślenie potoczne do dziś sprowadza zależność między tymi bytami do linearnej jednokierunkowej relacji, według której umysł lustrzanie odbija rzeczywistość, a język wiernie wyraża to odbicie. Ta interpretacja została najpierw podważona przez tzw. zwrot podmiotowy zainicjowany przez Kartezjusza (por. słynne: „Myślę, więc jestem”) i dokonany przez I. Kanta. Ten ostatni swoją kopernikańską rewolucją podważył jednokierunkowość relacji rzeczywistość - umysł, dowodząc, iż umysł odgrywa w poznaniu aktywną rolę. W dyskusji nad stanowiskiem Kanta J.G. Herder i W. Humboldt zapoczątkowali zwrot językowy, wskazujący na aktywną rolę języka względem myślenia i rzeczywistości. Rezultatem obu zwrotów było 
przeistoczenie jednokierunkowej linearnej relacji w bardziej złożony schemat, który można by przedstawić w postaci trójkąta. Jego wierzchołki symbolizują owe byty, natomiast boki relacje dwustronnej, wzajemnej interakcji.

Światopogląd pozytywistyczny traktował całą rzeczywistość przedmiotowo i głosił jedność nauki (metody i języka) oraz stawiał za wzorcowe nauki przyrodnicze, zwłaszcza fizykę, krytycznie odnosząc się do naukowości nauk humanistycznych. Przyczynił się także do wykreowania niewidzialnego ideału nauki nowożytnej, obejmującego trzy kluczowe wartości: Prawdę, Racjonalność i Obiektywizm, oraz cztery normy: Uniwersalizm, Wspólnotowość, Bezinteresowność i Krytycyzm (zob. Merton, 2002).

Ostatnie półwiecze przyniosło w aurze intelektualnej nauki - zwłaszcza w obszarze nauk humanistycznych i społecznych - znaczne zaburzenia. Można mówić wręcz o kolejnym, postmodernistycznym przełomie antynaturalistycznym (antypozytywistycznym) (por. przełomy wcześniejsze - pierwszy, z pogranicza wieku XVIII i XIX, związany z takimi postaciami jak G. Vico, I. Kant, J.G. Herder i W. Humboldt, oraz drugi, z drugiej połowy XIX wieku, związany z postaciami H. Rickerta i W. Diltheya). Istotą przełomów było ujawnienie i wyostrzenie się sporu o status humanistyki między podejściem podmiotowym (antynaturalistycznym) a ujęciem przedmiotowym (naturalistycznym), stawiającym badacza na zewnątrz wyjaśnianego świata. Podejście podmiotowe uwzględnia tzw. współczynnik humanistyczny badanych zjawisk, czyli sens, jaki wiążą z nimi ludzie, kładzie nacisk na ich zrozumienie. Dziś wygasł już impet tego ostatniego przełomu (m.in. M. Foucault, J. Derrida). Próbuje się łączyć oba podejścia. Warto więc przywołać określenia wskazujące na pewne fazy w rozwoju najnowszej nauki (zwłaszcza humanistyki): nowoczesność - ponowoczesność - po-ponowoczesność (nowa humanistyka).

Nowa humanistyka zdaje się przyjmować m.in. następujące przekonania, które stanowią o obliczu współczesnej naukowej aury intelektualnej i wpływają w jakimś stopniu i w jakiejś części na sposób uprawiania nauki w poszczególnych dyscyplinach:

- rzeczywistość nie pod każdym względem jest dana (umiarkowany realizm), pod pewnym względami - ona sama i jej obraz - jest konstruowana,

- poznawanie ludzkie cechuje wielość perspektyw i dróg, stanowisk poznawczych, stąd nieunikniony pluralizm ujęć, ale i dążność do integracji wiedzy,

- wiedza o świecie to wytwór ucieleśnionego oraz usytuowanego kulturowo i językowo umysłu,

- rozwój wiedzy naukowej przebiega nie tylko w sposób ciągły i linearny, lecz również skokowo (por. ideę rewolucji naukowych T. Kuhna), 
- trzeba docenić znaczenie porządnych badań empirycznych z rygorystycznym warsztatem metodycznym,

- konieczne jest rozwijanie, obok czystej nauki akademickiej, również nauki praktycznej (odpowiadającej na wyspecjalizowane zamówienia z różnych sfer ludzkiego życia) oraz publicznej (włączającej się w dyskurs publiczny, dotyczący ważnych kwestii społecznych).

A zatem ideał nauki nowożytnej w zasadzie nie został obalony czy odrzucony. Jego wartości i normy zyskały bardziej realistyczną, szerszą i głębszą, otwartą interpretację.

\section{4.}

Aura intelektualna ogólnonaukowa czy panująca tylko w naukach humanistycznych nie przesądza jednoznacznie o charakterze przekonań wybieranych do tworzonej bazy filozoficznej pełnej teorii. Wydaje się jednak, iż w kwestii założeń ontologicznych decydujący wpływ może mieć ontologia wychodząca od doświadczeń poznającego podmiotu (zob. Stróżewski, 2004). Przyjmuje ona, że podstawą tych doświadczeń jest istnienie, które przejawia się zawsze w postaci określonego sposobu istnienia. Sposoby są konstytuowane przez coś, co da się doświadczeniowo wypatrzeć i abstrakcyjnie uchwycić. Można więc przyjąć natępujące główne założenia ontologiczne:

1) rzeczywistość przejawia się w czterech sposobach istnienia (kryteria: obiektywny/przedmiotowy vs subiektywny/podmiotowy, jednostkowy $v s$ zbiorowy,

- obiektywny świat konkretnych jednostkowych przedmiotów (świat $\mathrm{TO}$ ),

- interobiektywny, abstrakcyjny świat, który można przedstawić jako system czy raczej jako system (sieć) systemów (świat TE obejmujący wiele światów TEN),

- subiektywny, podmiotowy świat jednostki, czyli jej świadomość (świat JA),

- intersubiektywny (międzypodmiotowy) świat określonych zbiorowości, czyli świadomość zbiorowa (świat MY),

2) wszystkie sposoby stanowią złożoną całość, wzajemne się warunkującą,

3) rzeczywistości aspektowe (np. językowa, edukacyjna) to integralne składowe całościowej rzeczywistości.

W wyróżnianiu sposobów istnienia rzeczywistości nawiązuje się do koncepcji trzech światów K. Poppera (1992), który wskazuje: 1. świat fizyczny, 2. świat mentalny (doświadczeniowy) i 3. świat idealny (obiektywnych treści myślowych), a także do ujęcia J. Habermasa (1999-2002) wydzielającego 
1. obiektywny świat TO, 2. subiektywny świat JA i 3. społeczny świat MY (świadomość zbiorową).

W epistemologii od wieków wielkim problemem był rozdźwięk między poznawaniem świata obiektywnego, przedmiotowego, tj. światów TO i TE/ TEN, a świata subiektywnego, podmiotowego (ściślej podmiotowo-przedmiotowego, gdyż podmiotowość bez przedmiotowego dopełnienia nie jest możliwa), czyli światów JA i MY. Nowsza epistemologia (m.in. pod wpływem przełomów antypozytywistycznych, ale też konsekwencji filozoficznych odkryć w fizyce i matematyce) łagodzi dualizm naturalizm - antynaturalizm i sprzyja integracji podejść przedmiotowego i podmiotowego. Dopełnia determinizm biologiczno-środowiskowy i społeczno-kulturowy podmiotowością, tj. emocjonalnością, intencjonalnością i składnikiem aksjonormatywnym (por. Hohol, 2013).

Współczesna aura intelektualna skłania więc do uwzględnienia szerokiego tła ontyczno-epistemicznego, tj. do liczenia się z bardzo złożoną i dynamiczną rzeczywistością przyrodniczą oraz społeczno-kulturową, a w konsekwencji z szerokim pluralizmem poznawczym, któremu powinno towarzyszyć komplementarne dążenie do integracji. Przed poznającym podmiotem rysują się cztery poznawcze perspektywy: do TO TE/TEN, JA i MY oraz cztery drogi poznawania dowolnego obiektu: od TO, TE/TEN, JA i MY. Pełne poznanie wymaga więc zastosowania wielu różnorodnych metod oraz integracji wielu cząstkowych wyników. Trzeba unikać przy tym redukcyjnego sprowadzania oglądu świata do perspektywy przedmiotowej.

Zejście na poziomy teoretyczno-metodologiczny i empiryczny wymaga ukierunkowania na główny przedmiot teorii. Jeśli budujemy teorię języka, to z przyjętych założeń ontologicznych wynika, iż rzeczywistość językową trzeba widzieć jako złożoną całość pozostającą wokreślonych relacjach $\mathrm{z}$ innymi składowymi globalnej rzeczywistości. Cztery sposoby istnienia rzeczywistości językowej to:

- konkretne komunikacyjne działania i ich tekstowe wytwory (TO językowe),

- system językowy (TEN językowy),

- indywidualna świadomość językowa (JA językowe),

- zbiorowa świadomość językowa (MY językowe).

W ten sposób pojęcie „język” wchodzi w bardzo rozbudowaną sieć pojęć teoretycznych i empirycznych, powiązanych różnorodnymi relacjami. Powstająca dzięki temu przestrzeń teoretyczna niekoniecznie musi przyjąć postać eleganckiej, spójnej teorii. Znacznie częściej ta przestrzeń znajduje się w ciągłej przebudowie. Pewne jej fragmenty mogą być w miarę uporząd- 
kowane, inne cechuje chaos poznawczy i występowanie konkurencyjnych niewspółmiernych ujęć.

3.

Przejdźmy teraz do języka. Podręczniki szkolne definiują go następująco: to system znaków, który służy do komunikowania się ludzi. Ta definicja została sformułowana pod wpływem dominującego w XX w. paradygmatu strukturalistycznego. Eksponuje się w niej jeden ze sposobów istnienia rzeczywistości językowej - TEN. Natomiast skryte są inne sposoby, czyli:

- TO, działanie językowe przy pomocy tekstów,

- JA językowe, czyli neuropsychiczna strona mowy (świadomość językowa, kompetencja),

- MY językowe, tj. świadomość językowa określonych zbiorowości.

Rzeczywistość językowa zatem to złożone sprzężenie wszystkich czterech sposobów. Nie istnieje i nie funkcjonuje całkowicie autonomicznie - jest zależna od kontekstu i ten kontekst współtworzy. Kiedy chcemy mówić o języku naukowym, nie możemy ignorować całej rzeczywistości naukowej, której język jest składową.

Trudno całkowicie zgodzić się z Einsteinem, który o językowym obliczu nauki mówił: zostawcie elegancję szewcom i krawcom, dla uczonego najważniejsze jest „co”, a nie „jak”. Można żachnąć się na podtytuł książki J. Maćkiewicz (2014) - którą bardzo polecam do samouczenia się - JAK DOBRzE PISAĆ. OD MYŚLI DO TEKSTU. Ten podtytuł może być interpretowany w duchu linearnego schematu: rzeczywistość-umysł-język. Język nie tylko wyraża to, co w umyśle, i przekazuje informacje, lecz także:

- wpływa na nasze poznanie, emocje i na intelekt (funkcja poznawcza),

- oddziałuje na samą rzeczywistość (funkcja sprawcza),

- buduje ludzkie zbiorowości, wspólnoty (funkcja socjalizująco-integracyjna).

W nowszych dziejach nauki (od XIX w.) wykształciło się kilka tzw. intelektualnych stylów. Na styl naukowego pisania w Polsce najpierw silnie oddziaływał tzw. styl teutoński, skoncentrowany na rzeczy, tj. na jej precyzyjnym i logicznym przedstawieniu, co wyrażało się m.in. w dokładnym definiowaniu i wyostrzaniu pojęć, w dbałości o poprawność i pełność wnioskowań. Teutońskie teksty nasycone były terminami i długimi zdaniami. Ten styl do dziś mocno trzyma się w nauce niemieckiej. W Polsce jego ciężką postać znacznie obniżyła filozoficzno-logiczna szkoła lwowsko-warszawska K. Twardowskiego ze swoim postulatem jasności. W okresie międzywojennym wywarła ona decydujący wpływ na kształt stylowy polskiej humanistyki. Znacznie mniej 
ważący był wpływ stylu galicyjskiego, dbającego o elegancję formy językowej tekstów, ceniącego lekkość i błyskotliwość przede wszystkim. Po II wojnie światowej stopniowo dominującą rolę w nauce światowej przejęła nauka amerykańska, preferująca styl saksoński, i on od ćwierćwiecza wywiera duży wpływ na polskie pisarstwo naukowe. Najkrócej można go scharakteryzować przywołanym na wstępie zdaniem: „Pisz/mów do rzeczy i do ludzi”, czyli pisz/mów, gdy masz coś ważnego do powiedzenia, kierując na to uwagę czytelników/słuchaczy. Kluczem do dobrego stylu jest więc widzenie świata, tzn. trzeba mieć coś oryginalnego do powiedzenia, oraz współpraca z odbiorcami (rozmowa, dialog). Trzeba unikać tego, co przeszkadza w odsłanianiu świata i przekazaniu jego obrazu czytelnikowi.

Tytuł książki Maćkiewicz, podobnie jak tytuł książki S. Pinkera (2016) - Pif̨kny styl. Przewodnik czŁowieka myślącego po sztuce pisaNIA XXI WIEKU - którą równie gorąco polecam - wskazuje, że ich autorzy koncentrują się na komunikacji pisemnej. Ma to swoje uzasadnienie historyczno-,techniczne”. Nie bez racji narodziny nauki w antycznej Grecji łączy się z opanowaniem sztuki pisania alfabetycznego, co odciążyło ludzki umysł od zapamiętywania, pozwalając mu wykorzystać swój potencjał w myśleniu bardziej szerokim, zdysyplinowanym i abstrakcyjnym. Jednak w naukowej sferze działalności ludzkiej ciągle olbrzymią rolę odgrywa komunikacja ustna, i ta bardziej formalna (wykład, referat), i ta nieformalna (rozmowy, konsultacje). Dziś na oblicze komunikacji w nauce wpływa internet. Niemniej to pismo stanowi dotąd jądro komunikacji w nauce, a artykuł i, mimo wszystko, monografia w naukach humanistycznych są podstawowymi gatunkami.

Rezygnuję ze szczegółowego przedstawiania repertuaru środków, które budują teksty naukowe, a także odznaczających się wariancją reguł ich użycia. Przywołam tu tylko całościową złożoną kategorię stylu, którą definiuję jako humanistyczną strukturę tekstu, obejmującą plan treści, plan wyrażania oraz kontekst komunikacyjny i społeczno-kulturowy. Wchodząc w życie, stykamy się z wieloma stylami zbiorowymi i indywidualnymi (styl naukowy, artystyczny, potoczny; styl Suchodolskiego, Miłosza) i wyrabiamy sobie indywidualne poczucie stylu, czyli w zetknięciu z TO (konkretnymi tekstami) z różnymi MY i JA budujemy własne JA stylowe, które jest rezultatem zewnętrznych determinantów, ale też podmiotowych decyzji.

Jak stać się dobrym stylistą? Nie ma prostych recept. Pomijając kwestię talentu, sądzę, że trzeba nad tym pracować. Jak? Przede wszystkim:

- kształtować swoją stylową wrażliwość przez obcowanie z wieloma różnymi tekstami, czyli przez lekturę różnych tekstów (nie tylko nauko- 
wych ze swojej dyscypliny z ostatnich kilku lat, lecz także klasyków dyscypliny, filozofów, artystów, innodyscyplinowych),

- pracować nad własnymi tekstami (przeczytać je na głos, po pewnym czasie, dać innej osobie do przeczytania),

- zapoznać się krytycznie z różnego rodzaju poradnikami, słownikami (np. Maćkiewicz, Pinker).

\section{BIBLIOGRAFIA}

Bińczyk, E., Derra, A., Grygieńć J. (red.). (2015). Horyzonty konstruktywizmu. Inspiracje, perspektywy, przyszłość. Toruń: Wydawnictwo Naukowe UMK.

Habermas, J. (1999-2002). Teoria działania komunikacyjnego (t. 1-2). Warszawa: Wydawnictwo Naukowe PWN.

Hohol, M. (2013). Wyjaśnić umysł. Struktura teorii neurokognitywnych. Kraków: Copernicus Center Press.

Maćkiewicz, J. (2014). Jak dobrze pisać. Od myśli do tekstu. Warszawa: Wydawnictwo Naukowe PWN.

Merton R. (2002). Teoria socjologiczna i struktura społeczna. Warszawa: Wydawnictwo Naukowe PWN.

Pinker, S. (2016). Piękny styl. Przewodnik człowieka myślącego po sztuce pisania XXI wieku. Przeł. A. Nowak-Młynikowa. Sopot: Wydawnictwo Smak Słowa.

Popper, K. (1992). Wiedza obiektywna. Ewolucyjna teoria epistemologiczna. Warszawa: Wydawnictwo Naukowe PWN.

Stróżewski, W. (2004). Ontologia. Kraków: Aureus-Znak.

Zeidler, P. (1993). Spór o status poznawczy teorii. W obronie antyrealistycznego wizerunku na$u k i$. Poznań: Wydawnictwo Naukowe IF. UAM.

Zybertowicz, A. (1995). Przemoc i poznanie. Toruń: Wydawnictwo UMK.

\section{SUMMARY}

\section{Language in science: the philosophical-linguistic perspective?}

The core of scientific research procedure is the intention to develop a theory. The structure of a complete theory involves three levels: philosophical (a set of a priori ontological and axiological assumptions), theoretical/methodological (most general statements and abstract concepts, conceptualizing, structuring and interpreting the fragment of the world the theory refers to) and empirical (empirical statements and concepts involving certain declarations concerning the studied objects). The philosophical foundations of contemporary theories in the humanities should involve the reinterpretation of relationships between the material world, mind and language with the use of expressions such as "subjective" and "linguistic", and acknowledge the multiplicity of ways in which the reality may exist (objective: THIS and THESE and subjective: ME and US). As a result, the complete theory of language must assume that language does not only express what is on someone's mind and communicates it to others, but it also shapes human thinking and affects the objective reality. Language in science is determined by the socio-cultural context (tradition) and the communication context, but it is also affected by individual, subjective stylistic sense.

KEY WORDS: science, theory, ways in which the reality exists, language, intellectual styles, stylistic sense 